\title{
Values, Environmental
}

HOLMES ROLSTON III

Colorado State University, United States

\section{Values in and of nature}

The classic idea is that aspects of the natural environment have both instrumental values and intrinsic (or inherent) values. Animals value the food on which they graze or the prey that they catch. Humans value natural resources. Plants, animals, and humans value their own lives and their offspring; they have a good of their own. They are naturally selected to be good adapted fits in their environments. Other environmental factors may have disvalues, such as storms, diseases, drought, or one's predators.

A third concept is that virtuous humans ought to value relevant environmental values in both instrumental and intrinsic ways. Such values arise with human preferences; absent humans, no values exist in nature. That leaves some 3.5 billion years of pre-human life on earth valueless.

A further account is that at ecosystem levels nature has systemic values. Individuals need their supporting systems. Although conflict is part of the picture, the organism has a situated environmental fitness. We want to value the lush life that is maintained by ecosystems-their diversity, unity, dynamic stability, and spontaneity; the dialectic of environmental resistance and conductance; and the creative life forces. We should likewise value environmental justice.

\section{Anthropocene values}

One would think that anthropologists would be interested in the Anthropocene epoch. In this forthcoming geological epoch, humans can and ought to reengineer the earth as a synthetic planet that will serve us better. The dream of living in harmony with nature is past. There is a more promising ambition: audacious humans managing their brave new world.

David Biello, Scientific American's energy and environment editor, writes:

The stakes could not be higher ... What we stand to gain is nothing less than an enduring civilization and a firmer understanding of our planet and ourselves. We have arrived at a new geologic epoch of our own making ... I argue the goal must be to make an enduring Anthropocene, an epoch that, in geologic and civilizational terms, stretches into an era ... This is not the end of the world. This is just the end of the world as we have known it. (Biello 2016, 7-8)

What we must push for, according to the Royal Society, is the "sustainable intensification" of reaping the benefits of exploiting the earth (Royal Society 2009). "Instead 
of pursuing the protection of biodiversity for biodiversity's sake, a new conservation should seek to enhance those natural systems that benefit the widest number of people, especially the poor" (Kareiva, Lalasz, and Marvier 2011, 36-37). Kareiva and Marvier urge us to shift "from a focus almost exclusively on biodiversity" to more attention to "human well-being ... Today we need a more integrative approach in which the centrality of humans is recognized" $(2012,963)$.

It is claimed that putting humans at the center is morally better, but behind this saving nature for people may be as much a problem as an answer, for essentially this makes us the first, if not the only, location of moral relevance. The geoengineers may find a majority of earth's residents wondering: Is our only relationship to nature one of engineering it for the better?

\section{Ecosystem values and services}

The Ecological Society of America says: "Achieving a sustainable biosphere is the single most important task facing humankind today" (Risser, Lubchenco, and Levin 1991). Using scientific data, Johan Rockström (2009) argues that there are nine planetary systems on which humans depend: chemical pollution; climate change; ocean acidification; stratospheric ozone depletion; biogeochemical nitrogen-phosphorus cycles; global freshwater use; changing land use; biodiversity loss; and atmospheric aerosol loading. In the three italicized systems the boundaries have already been exceeded (Rockström 2009). All nine of these must be pivotal environmental values at risk, and the three of immediate concern.

In 2018 the United Nations Intergovernmental Panel on Climate Change (IPCC) issued a devastating report that limiting global warming to 1.5 degrees Celsius, which would have clear benefits for people and natural ecosystems, would require rapid, far-reaching, and unprecedented changes in all aspects of society (IPPC 2018; United Nations 2018).

Perhaps the most celebrated environmental ethic is that of Aldo Leopold, a forester and ecologist. His A Sand County Almanac proved one of the landmark books of the last century: "A thing is right when it tends to preserve the integrity, stability, and beauty of the biotic community. It is wrong when it tends otherwise." We ought to love "the land," he insisted, "the natural processes by which the land and the living things upon it have achieved their characteristic form (evolution) and by which they maintain their existence (ecology)." "That land is a community is the basic concept of ecology, but that land is to be loved and respected is an extension of ethics" (Leopold [1949] 1968, 224-25, 173, viii-ix).

\section{Spiritual values}

Yearning for a sense of place is a perennial human longing, for landscapes inhabited with care and love. The British love their countryside, while Americans sing, with goose pimples, "America the Beautiful." The promised land has been central in Hebrew 
faith. Ask people why the Grand Canyon or the Grand Tetons should be "saved," and the ready answer will be "Because they are 'grand." John Muir loved the High Sierras of California; Rachel Carson celebrated the sea and the spring birds; Bob Marshall treasured the wilderness in Montana. Both religious and secular individuals consider respect for creation as a spiritual value.

The photograph of earth seen from space is an emotionally moving one, especially when seen in pensive moments. It has been seen by more humans than any other photograph. Astronauts in space regularly report experiencing euphoria from what they have come to call "the overview effect." Over 200 astronauts, men and women from twenty nations, report being "earthstruck" (Kelley 1988). They come back from space psychologically changed-some spacy neuroscience under zero-G. For example, Edgar Mitchell, the Apollo 14 astronaut, described a profound sense of connectedness with a feeling of bliss and timelessness. He became profoundly aware that every atom in the universe was interconnected and, on seeing the earth from space, he realized how all humans, animals, and systems were part of the same thing; the event changed his life (White 2014). Viewing earthrise from the moon, Mitchell was entranced:

Suddenly from behind the rim of the moon, in long, slow-motion moments of immense majesty, there emerges a sparkling blue and white jewel, a light, delicate sky-blue sphere laced with slowly swirling veils of white, rising gradually like a small pearl in a thick sea of black mystery. It takes more than a moment to fully realize this is Earth ... home.

He continued: "My view of our planet was a glimpse of divinity" (Kelley 1988, at photographs 42,52 ). That might be the ultimate in environmental values.

SEE ALSO: Anthropocene, The; Anthropocentrism and Post-humanism; Environmental Activism; Environmental Justice; Environmentalism; Ethics and Morality, Anthropological Approaches to; Human/Environment Dichotomy; Nature, Concepts of; Philosophical Anthropology

\section{REFERENCES AND FURTHER READING}

Biello, David. 2016. The Unnatural World: The Race to Remake Civilization in Earth's Newest Age. New York: Simon \& Schuster.

IPCC (Intergovernmental Panel on Climate Change). 2018. Special Report: Global Warming of $1.5^{\circ} \mathrm{C}$. Accessed August 30, 2019, https://www.ipcc.ch/sr15.

Kareiva, Peter, Robert Lalasz, and Michelle Marvier. 2011. "Conservation in the Anthropocene. Beyond Solitude and Fragility." Breakthrough Journal 2 (Fall): 29-37. Accessed August 30, 2019, https://thebreakthrough.org/journal/issue-2/conservation-in-the-anthropocene.

Kareiva, Peter, and Michelle Marvier. 2012. "What Is Conservation Science?" BioScience 62: 962-69.

Kelley, Kevin W., ed. 1988. The Home Planet. Reading, MA: Addison-Wesley.

Leopold, Aldo. (1949) 1968. A Sand County Almanac. New York: Oxford University Press.

Risser, Paul G., Jane Lubchenco, and Samuel A. Levin. 1991. "Biological Research Priorities-A

Sustainable Biosphere.” BioScience 47: 625-27.

Rockström, Johan. 2009. “A Safe Operating Space for Humanity.” Nature 461: 472-75. 
Royal Society. 2009. Reaping the Benefits: Science and the Sustainable Intensification of Global Agriculture. London: Royal Society. Accessed September 2, 2019, https://royalsociety.org/-/ media/Royal_Society_Content/policy/publications/2009/4294967719.pdf.

United Nations. 2018. “Climate Change.” Accessed August 30, 2019, https://www.un.org/en/ sections/issues-depth/climate-change.

White, Frank. 2014. The Overview Effect: Space Exploration and Human Evolution. Reston, VA: American Institute of Aeronautics and Astronautics. 